\title{
DAMPAK KODE ETIK PADA PENGARUH FILOSOFI ETIS DAN INTENSITAS ETIS TERHDADAP PENGAMBILAN KEPUTUSAN ETIS AKUNTAN PUBLIK
}

\author{
Suryadi Winata \\ suryadiwinata@ymail.com \\ Universitas Buddhi Dharma, Tangerang \\ Khomsiyah \\ Universitas Trisakti, Jakarta
}

\begin{abstract}
The purpose of this study is to examine the role of ethical codes in strengthening the influence of ethical philosophy - idealism, relativism, and ethical intensity - magnitude of consequence, social consensus, temporal immediacy on ethical decision making (EDM). The research samples used are 138 public accountants. The hypotheses testing used is moderated regression analysis. The results shows that code of ethics reduce the influence of idealism to ethical awareness of public accountants. code of ethics and idealism are factors that are complementary, so the implications of the code of conduct is an importance tool for the implementation of idealistic thinking's in EDM practice of public accountants. Ethical codes that have reduced the positive influence of idealism on ethical awareness means that code of ethics promote each public accountant to follow universal ethics rules in achieving the best business results. The fact of the idealistic thoughts have strong influence on ethical awareness describes the powerful idealism, and then the strength of ethical codes that can reduce the effect of idealism in EDM means that the superiority of relativism as EDM basis. The combination between powerful idealism and superiority of relativism would be situationist's position in the taxonomy of ethical ideology.
\end{abstract}

Key words: code of ethic, ethical philosophy, ethical intensity, and public accountants.

\begin{abstract}
ABSTRAK
Tujuan penelitian ini adalah untuk mengukur peran kode etik dalam memperkuat pengaruh filosofi etis yaitu idealisme, relativisme, dan intensitas etis yaitu magnitude of consequence, social consensus dan temporal immediacy pada pengambilan keputusan etis. Sampel penelitian ini menggunakan 138 akuntan publik. Pengujian hipotesis menggunakan analisis regresi moderasi. Hasilnya memperlihatkan bahwa kode etik menurunkan pengaruh idealisme terhadap kesadaran etis akuntan publik. Kode etik dan idealisme merupakan faktor-faktor yang saling melengkapi, sehingga implikasi kode etik merupakan alat penting dalam rangka penerapan pemikiran kaum idealis pada praktik akuntan publik. Kode etik yang dapat menurunkan pengaruh positif idealisme terhadap kesadaran etis berarti bahwa kode etik mendorong setiap akuntan publik untuk mematuhi aturan etis universal dalam mencapai hasil usaha yang terbaik. Fakta yang menunjukkan pemikiran para idealis berpengaruh kuat terhadap kesadaran etis menggambarkan idealime yang kuat, dan adanya kode etik yang kuat yang dapat menurunkan pengaruh idealisme dalam pengambilan keputusan etis mengartikan kekuatan relativisme sebagai dasar pengambilan keputusan etis. Kombinasi antara idealisme dan relativisme kuat merupakan posisi situationis di dalam taxonomy of ethical ideology.
\end{abstract}

Kata kunci: kode etik, filosofi etis, intensitas etis, dan akuntan publik.

\section{PENDAHULUAN}

Perilaku etis akuntan profesional adalah penting terhadap status dan kredibilitas profesi akuntan karena sebagai agen per- kembangan moral di perusahaan-perusahaan akuntan sering berhadapan dengan dilema dalam memilih di antara nilai-nilai yang saling bertentangan (Leung dan 
Cooper, 2005; Chan dan Leung, 2006; Kareacer et al., 2009, dan Ionescu, 2010). Pemilihan nilai-nilai tersebut membutuhkan kemampuan melakukan pengambilan keputusan etis, selain kompetensi di dalam pemilihan metode akuntansi yang sesuai untuk pengukuran dan pengungkapan keuangan tertentu, di bawah tekanan yang berat dengan banyak keterbatasan (Leung dan Cooper, 2005; Gaffikin dan Lindawati, 2012).

Leung dan Cooper (2005) mengungkapkan bahwa secara total terdapat 6.693 isu etis yang berbeda-beda yang dihadapi oleh para anggota CPA di Australia pada 12 bulan terakhir tahun 2005. Akuntan publik banyak menghadapi dilema etis yang berat terutama yang berhubungan dengan isu-isu adanya tekanan klien. Penelitian Leung dan Cooper (2005) menggambarkan bahwa audit atas laporan keuangan perusahaan yang dilakukan oleh auditor independen (CPA) yang terdidik yang hanya mendapat pelatihan teknis saja, tidak cukup. Para auditor independen harus mampu mempertahankan pertimbangan etis yang merupakan intensinya (Leung dan Cooper, 2005).

Selain menjaga kepercayaan publik dan mengembangkan profesi akuntansi di masa depan, juga dibutuhkan peran auditor yang selalu memantau kualitas informasi keuangan perusahaan dan memastikan implementasi prinsip, standar, prosedur, konsep serta metode-metode akuntansi yang sesuai dengan kebijakan akuntansi yang telah ditetapkan, sehingga laporan keuangan yang dihasilkan memenuhi karakteristik kualitatif agar informasinya dapat dipahami, relevan, handal, dapat diperbandingkan, serta mengurangi asimetri informasi (Wolk et al., 2008).

Tugas akuntan yang selalu berhubungan dengan permasalahan etis dan integritas yang tinggi dalam setiap bidang dan tugas akuntansi mengambarkan bahwa permasalahan etika pada bidang akuntansi mempunyai kemiripan dengan masalah pengambilan keputusan etis (ethical decision making) oleh auditor, akuntan manajemen, dan akuntan praktisi pajak. Pengambilan keputusan etis (ethical decision making) atau $E D M$, di dalam praktik akuntansi salah satunya didasarkan pada pertimbangan etis yang terjadi, sehingga pertimbangan etis tersebut dapat mendukung kepercayaan dan keyakinan pada sistem pasar modal dengan penyimpangan yang minimal pada pelaporan keuangan (Barlaup et al., 2009).

Pertimbangan dan perilaku etis yang meningkatkan kepercayaan tentang penyimpangan yang minim dalam pelaporan keuangan dan menggambarkan bahwa pertimbangan moral berpengaruh pada keputusan investasi, menjadi alasan yang mendasar untuk melakukan penelitian di dalam implementasi pertimbangan etis yang lebih rumit (Hofmann et al., 2007; Pflugrath et al., 2007, dan Barlaup et al., 2009). Penerapan pertimbangan etis yang dilakukan oleh individu-individu digambarkan oleh Forsyth (1980) dengan mengembangkan taxonomy of ethical ideology yang mencoba melakukan persilangan pengaruh antara filosofi etis dimensi idealisme dengan dimensi relativisme dan mengungkapkan filosofi etis dengan empat dimensi yaitu; situationists, exceptionists, absolutists dan subjectivists. Penelitian ini menggambarkan proses penerapan filosofi etis pada praktik pengambilan keputusan etis oleh individu-individu.

Pertimbangan etis selain dipengaruhi idealisme dan relativisme juga dipengaruhi oleh intensitas etis yang merupakan faktor situasional individual. Intensitas etis mencoba menjelaskan suatu isu etis yang sudah dipertimbangkan diterima di dalam situasi tertentu. Terdapat tiga dimensi yang paling berpengaruh yaitu; magnitude of consequence, social consensus, dan temporal immediacy (Jones, 1991; Ng et al., 2009; dan Craft, 2013). Pertimbangan etis juga dipengaruhi oleh faktor situasional organisasional yang didasarkan pada pertimbangan individuindividu karena berada pada situasi kepentingan masing-masing di dalam suatu organisasi yang melakukan pengambilan keputusan etis (Ionescu, 2010). Faktor 
situasional yang umumnya mempengaruhi keputusan etis adalah pemberian penghargaan dan sanksi, penerapan kode etik dan terciptanya iklim etis (Ford dan Richardson, 1994; Leung dan Cooper, 2005).

Implementasi kode etik di dalam konteks pengalaman pelaksanaan audit yang umum mempunyai pengaruh positif pada kualitas kebijakan yang dilakukan oleh para akuntan profesional (Pflugrath et al., 2007). Kebutuhan adanya kode etik yang terus dikembangkan adalah untuk mempertahankan kepercayaan publik dalam integritas profesi akuntan, yang sejalan dengan fakta terjadinya peningkatan minat dalam penelitian yang bertujuan menguji kemampuan pertimbangan moral akuntan publik.

Motivasi dilakukannya penelitian tentang faktor-faktor individual dan situasional tertentu pada pengambilan keputusan etis dalam pengembangan ilmu dan implementasi praktik akuntansi adalah: pertama, penelitian tentang pengambilan keputusan etis selama ini telah banyak mengungkap arti penting faktor-faktor individual dan situasional terhadap pengambilan keputusan etis (Leung dan Cooper, 2005; Musbah, 2010; Jin, 2012; dan Craft, 2013). Namun, penelitian tentang etik dan kajian praktik di Indonesia masih terbatas. Kedua, Indonesia sebagai negara dengan beragam nilai budaya, konsekuensinya semua individu di dalam organisasi dan profesi yang ada harus mempertimbangkan keputusan etis yang dipengaruhi oleh beragam faktor yang berhubungan dengan pengambilan keputusan etis tersebut (Chan dan Leung, 2006 dan Musbah, 2010). Para akuntan berhadapan dengan suatu isu etis, akan melakukan investigasi untuk memahami jenis isu etis yang dihadapi tersebut, dan menentukan faktor-faktor individual atau situasional mana yang paling berpengaruh terhadap keputusan etis di dalam profesinya, sehingga dapat menghindarkan diri dari perilaku yang tidak etis. Tujuan penelitian ini adalah menguji dampak kode etik terhadap pengaruh filosofi etis dan intensitas etis pada pengambilan keputusan etis akuntan publik.

\section{TINJAUAN TEORETIS}

\section{Pengambilan Keputusan Etis}

Pengambilan keputusan merupakan aspek penting dalam akuntansi keperilakuan, karena aspek pengambilan keputusan memfokuskan pada teori dan model tentang pengambilan keputusan. Teori pengambilan keputusan adalah teori normatif yang menjelaskan bagaimana seharusnya individu-individu mengambil keputusan. Suartana (2010) menjelaskan bahwa model deskriptif pengambilan keputusan menjelaskan fakta-fakta empirik yang terjadi sebagai dasar, ketika individu-individu tersebut melakukan pengambilan keputusan.

Proses pengambilan keputusan etis digambarkan dalam tahap-tahap yang serupa dengan proses pengambilan keputusan manajemen yang diungkap oleh Gilbert et al. (2009). Kesadaran etis serupa dengan identifikasi situasi, pertimbangan etis serupa dengan proses kreatif pengembangan alternatif-alternatif keputusan yang akan dievaluasi atau dipertimbangkan lebih lanjut. Kemudian alternatif keputusan yang dikembangkan dievaluasi atau dikaji ulang untuk mendapat alternatif yang terbaik, sehingga proses ini dapat memilih alternatif untuk dilaksanakan suatu tindakan yaitu alternatif keputusan yang paling terbaik. Alternatif pengambilan keputusan yang sudah teruji mempunyai kekuatan pada tahap intensi etis. Lebih lanjut implementasi alternatif terbaik keputusan yang telah dipilih merupakan perilaku etis dalam pengambilan keputusan etis.

Keputusan etis didefinisi sebagai "suatu keputusan yang secara hukum dan etik dapat diterima di dalam masyarakat yang lebih luas. Kebalikannya adalah suatu keputusan yang dikatakan tidak etis adalah yang secara hukum atau etik tidak dapat 
diterima di dalam masyarakat yang lebih luas. Sementara definisi pengambilan keputusan etis yang lain menjelaskan bahwa pengambilan keputusan etis sebagai "suatu proses dilakukan individu-individu yang menggunakan dasar pemikirannya untuk menentukan apakah suatu isu tertentu adalah benar atau salah" (Jones, 1991).

\section{Model Pengambilan Keputusan Etis}

Model pengambilan keputusan etis yang paling komprehensif adalah yang dibuat oleh Jones (1991). Model tersebut mengintegrasi model keputusan etis sebelumnya dan merepresentasi secara menyeluruh variabel-variabel yang sudah di sepakati berpengaruh terhadap pengambilan keputusan etis dan memperkenalkan suatu konsep intensitas etis. Jones meyakini bahwa studi sebelumnya masih terbatas dalam membahas isu-isu etis sampai faktor yang menjadi penyebab. Intensitas etis adalah "perluasan dari isu yang terkait dengan perintah etis yang harus dilakukan di dalam situasi tertentu."

Fondasi model Jones tersebut menggambarkan empat tahap proses; pengakuan isu-isu etis (ethical awarness/recognizing), pembentukan pertimbangan etis (ethical judgment development), penetapan intensi etis (establishing ethical intent), dan keterlibatan di dalam perilaku etis (engaged in ethical behavior). Model empat tahap tersebut menghubungkan model pengambilan keputusan etis yang positif dan mengasumsikan bahwa pilihan etis adalah bukan hanya keputusan individual, namun ditentukan oleh pembelajaran sosial di dalam suatu organisasi. Lin dan Ho (2008) menggunakan model Jones dengan membagi 4 tahap pengambilan keputusan etis yaitu kesadaran etis, pertimbangan etis, intensi etis, dan perilaku etis.

Selanjutnya, Jones (1991) telah mengembangkan berbagai faktor terkait etis menjadi komponen tertentu intensitas etis ke dalam model proses pengambilan keputusan etis. Jones mengungkap bahwa orang akan bereaksi berbeda pada isu-isu etis dalam hal bahwa secara sistematik berhubungan dengan karakteristik isu itu sendiri, kemudian menyatakan bahwa karakteristik tertentu dari isu etis itu sendiri adalah penentu penting dari proses pengambilan keputusan etis. Model Jones (1991) digunakan juga oleh Dickerson (2009) untuk menguji sensivitas etis dalam pengambilan keputusan etis auditor (akuntan publik). Secara tradisional, empat tahap pengambilan keputusan etis yaitu pengakuan etis, pertimbangan etis, intensi etis dan perilaku etis seolah-olah merupakan suatu hasil temuan etik yang paling akhir, sementara itu para peneliti juga telah menginvestigasi variabel individual ( $\mathrm{Lv}$ dan Huang, 2012; dan Craft, 2013), variabel organisasional dan karakteristik intensitas etis sebagai variabel prediktor (Craft, 2013).

\section{Kesadaran Etis}

Kesadaran etis (ethical awareness) disebut juga dengan istilah pengakuan etis (ethical recognition) atau sensitivitas etis (ethical sensitivity) adalah suatu tahap yang mendasar dan penting di dalam proses pengambilan keputusan etis. Mengakui suatu isu menjadi isu etis secara moral dapat membantu dalam mempertimbangkan pengambilan keputusan etis. Jones (1991) mengungkapkan bahwa pengakuan adanya isu-isu etis meliputi dua komponen penting dalam mengidentifikasi isu-isu etis: 1) individu harus merealisasi bahwa tindakannya akan mempengaruhi kesejahteraan orang lain dan 2) individu mempunyai kemauan sendiri di dalam isu tersebut. Selanjutnya, ketika individu-individu gagal mengidentifikasi isu etis tersebut, mereka tidak punya lagi kesempatan untuk melanjutkan pada tahap berikutnya dalam suatu proses pengambilan keputusan etis, sehingga keputusan mereka akan dibuat sesuai pada aspek lain misalnya motivasi ekonomi.

Studi empirik Chan dan Leung (2006) dan Croxford (2010) mengungkapkan bahwa pengakuan etis adalah bersyarat di atas variabel-variabel individual (umur, jender, 
tingkat pendidikan dan yang lainnya), variabel-variabel organisasi (kode etis, iklim etis, pengaruh manajemen puncak, dan sebagainya) dan konten-konten tertentu dari isu intensitas etis (besarnya konsekuensi, konsensus sosial, kemungkinan pengaruh dan sebagainya).

\section{Pertimbangan Etis}

Tahap kedua dari proses pengambilan keputusan etis adalah tahap pertimbangan etis atau ethical judgement. Tahap ini mempunyai dasar utama pada tahap perkembangan moral kognitif (cognitive moral development) yang dikembangkan oleh Kohlberg. Teori perkembangan moral kognitif dari Kohlberg telah dijadikan landasan teoretis untuk berbagai versi teori pengambilan keputusan etis (Haines dan Leonard, 2007; Lv dan Huang, 2012). Model tersebut mencoba menghubungkan pertimbangan etis pada perilaku etis dan mengusulkan bahwa faktor-faktor individual mempengaruhi hubungan menyeluruh pada proses pengambilan keputusan yang lebih terpadu, daripada hanya sekedar pertimbangan apakah suatu isu dapat diterima atau tidak secara etis (Haines dan Leonard, 2007).

\section{Intensi Etis}

Tahap ketiga dari proses pengambilan keputusan etis di dalam model yang dikembangkan oleh Jones (1991) adalah intensi etis. Jones (1991) memperkuat definisi sebelumnya bahwa intensi etis adalah "tingkatan tertentu dari komitmen untuk mengambil serangkaian tindakan, penempatan nilai-nilai moral di atas nilai-nilai lain, dan mengambil tanggung jawab personal untuk hasil-hasil yang etis." Jones (1991) juga mengatakan bahwa intensi etis adalah motivasi etis, meskipun Shaw (2006) mempunyai argumentasi berbeda yang mengatakan bahwa intensi etis bukan motivasi etis, karena motivasi etis adalah suatu motivasi untuk melakukan sesuatu yang merupakan tujuan dari tindakan tertentu yang ditujukan pada realisasi suatu tujuan akhir.

Namun demikian, terdapat argumentasi yang mendukung bahwa intensi diasumsikan untuk melihat faktor-faktor motivasi yang mempengaruhi suatu perilaku, sehingga hal tersebut merupakan indikasi sebagaimana kerasnya seorang akan berusaha mencoba, atau berapa banyak upaya tertentu yang mereka rencanakan untuk mendesak dalam rangka mencapai perilaku tersebut. Intensi etis sebagai suatu teori dapat dihipotesiskan lebih kuat suatu intensi untuk terlibat di dalam perilaku, maka cenderung akan lebih kuat mencapai kinerja perilaku etis tersebut (Ajzen, 1991).

\section{Perilaku Etis}

Tahap terakhir dari proses pengambilan keputusan etis adalah perilaku etis. Dalam hal ini individu terlibat dalam suatu tindakan yang paling baik sebagai hasil dari intensi etis mereka. Perilaku etis didefinisikan sebagai satu dari kedua hal yaitu secara hukum atau etis adalah perilaku yang dapat diterima oleh suatu masyarakat (community) yang lebih besar (Jones, 1991). Perilaku etis adalah hasil dari proses yang beragam dan rumit. Ruang lingkup penelitian etis umumnya tidak sampai pada perilaku etis, karena perilaku etis meliputi pemantauan tindakan yang dilakukan secara nyata dalam jangka waktu panjang.

Alasan secara teoretis dapat mengambil referensi pada teori tindakan yang dipertimbangkan (Theory of Reasoned Action (TRA)) dan teori perilaku yang terencana (Theory of Planned Behaviour (TPB)) (Ajzen, 1991). Dalam pembahasan tentang intensi etis, ditemukan bukti yang menyarankan: Pertama; TPB memberikan suatu perkiraan determinan-determinan tertentu perilaku etis, bilamana ada keduanya yaitu motivasi dan kesempatan yang tinggi untuk proses informasi yang jelas, kedua; perluasan $T P B$ dalam rangka menjelaskan hubungan inten- 
si dengan perilaku lebih lanjut dapat memberikan cara untuk mengembangkan TPB dalam hubungannya dengan bagaimana memahami suatu sikap atau pendapat umum tentang moral (moral norms) dapat berdampak pada pencapaian perilaku etis (Buchan, 2005).

\section{Filosofi Etis}

Ferrell et al. (2011), menjelaskan definisi dari faktor tersebut sebagai berikut ini "filosofi etis adalah perspektif etis ideal yang memberi kepada individu-individu, suatu dasar yang abstrak untuk menuntun keberadaan sosial mereka." Banyak teori dihubungkan dengan filosofi etis yang terkait pada suatu orientasi nilai dan setiap nilai-nilai seperti ekonomi, idealisme, dan relativisme. Suatu konsep orientasi nilai ekonomi tertentu yang dihubungkan dengan nilai yang dapat dikuantifikasi dalam pengertian uang; jadi berdasarkan pada teori ini, apabila suatu tindakan yang mempunyai nilai lebih dari pada upaya yang dilakukan, selanjutnya hal tersebut dapat diakui sebagai suatu yang etis.

Idealisme, disatu sisi adalah suatu filosofi etis yang menempatkan nilai khusus pada ide-ide dan idealnya sebagai suatu produk pemikirannya, dalam perbandingan dengan apa yang menjadi pandangan yang ada di dunia. Terminologi tersebut merujuk pada upaya-upaya untuk dapat menghitung semua obyek dari alam dan pengalaman serta bertujuan untuk menghasilkan sesuatu yang lebih tinggi manfaatnya. Beberapa penelitian telah mengungkap bahwa terdapat suatu hubungan positif antara pemikiran idealistik dan pengambilan keputusan etis (Chan dan Leung, 2006; Callanan et al., 2010; dan Craft, 2013).

Relativisme adalah suatu pandangan bahwa dunia luar yang ada tidak terikat dengan persepsi individu tentang dunia luar tersebut. Relativisme bekerja berdasarkan pada asumsi tertentu bahwa kebaikan manusia adalah bukan suatu sifat kebajikan dan kebaikan hati yang sudah ada dari asalnya tetapi sebaliknya merupakan suatu yang sudah harus diusahakan sendiri dan bersaing untuk mendapatkannya. Berdasarkan pada pemikiran kaum relativistis, setiap orang selalu dengan sendirinya dituntun oleh kepentingannya sendiri. Hasil penelitian memperlihatkan suatu hubungan negatif antara pemikiran relativistik dan pengambilan keputusan etis. Jadi, suatu keyakinan bahwa semua tindakan adalah disebabkan oleh motivasinya sendiri yang pada akhirnya cenderung menuju pengambilan keputusan etis yang negatif (Callanan et al., 2010 dan Ferrell et al., 2011).

Individu-individu yang memperlihatkan tingkat idealisme yang lebih tinggi lebih memilih opsi yang lebih etis dibandingkan mereka yang memperlihatkan idealisme yang lebih rendah. Terdapat juga hubungan yang signifikan antara orientasi etis, komitmen organisasi, dan benefit perorangan dengan pengambilan keputusan, termasuk juga intensi manajemen laba (Greenfield et al., 2007; Callanan et al., 2010).

\section{Intensitas Etis}

Definisi intensitas etis menurut (Jones, 1991; Craft, 2013) adalah "suatu kontruks yang dapat menjelaskan suatu isu yang luas yang berhubungan dengan suatu penjelasan etis di dalam situasi tertentu." Terdapat enam dimensi yang membentuk intensitas etis (ethical intensity) sesuai dengan definisi di atas yaitu; (1) besarnya konsekuensi (magnitude of consequences), (2) konsensus sosial (social consensus), (3) dampak yang mungkin terjadi (probability of effect), (4) kedekatan waktu (temporal immediacy), (5) kemiripan (proximity), serta (6) luasnya dampak yang diakibatkan (concentration of effect) (Ng et al., 2009; Craft, 2013).

Dimensi besarnya konsekuensi didefinisikan sebagai berapa besarnya kerugian atau keuntungan yang dapat diperhitungkan pada pihak-pihak yang dirugikan atau yang diuntungkan dalam hubungannya dengan suatu tindakan etis (Musbah, 2010). Dimensi konsensus sosial didefinisikan sebagai tingkatan besarnya persetujuan sosial masyarakat pada tindak- 
an yang diusulkan adalah baik atau buruk di dalam praktiknya ( $\mathrm{Ng}$ et al., 2009 dan Musbah, 2010). Hal tersebut mengindikasi kesadaran individu atas diterima atau tidaknya suatu tindakan hukum tertentu.

Dimensi ketiga dari intensitas etis adalah kemungkian dampak yang terjadi (probability of effect) yaitu kemungkinan dampak yang terjadi dari suatu tindakan etis yang berfungsi menghubungkan kemungkinan bahwa fakta tertentu yang masih dipertanyakan akan sesungguhnya terjadi dan tindakan yang dipertanyakan tersebut akan sungguh-sungguh menyebabkan kerugian atau keuntungan yang dapat diperkirakan (Ng et al., 2009).

Dimensi berikutnya kedekatan waktu dan kemiripan (temporal immediacy and proximity) merupakan panjangnya waktu untuk konsekuensi suatu tindakan etis dari mulai dipertanyakan saat ini sampai dengan terjadinya konsekwensi yang nyata (Ng et al., 2009 dan Musbah, 2010). Dimensi kemiripan (proximity) dari isu etis tertentu adalah suatu perasaan sosial, budaya, psikologis, atau fisik di mana seorang agen moral dipertanyakan mendapatkan sanksi atau penghargaan baik (victims or beneficiaries) dari tindakan pihak yang jahat atau yang baik (evils or beneficial) ( $\mathrm{Ng}$ et al., 2009).

Dimensi terakhir adalah luasnya dampak dari suatu tindakan etis yang diterjemahkan dari (concentration of effect of the moral act) adalah kebalikan fungsi dari banyaknya orang yang terpengaruh oleh dampak tindakan etis tertentu yang sudah terjadi ( $\mathrm{Ng}$ et al., 2009). Sebagai contoh, pencurian uang atau korupsi senilai sepuluh juta rupiah yang dilakukan oleh seorang karyawan di perusahaan perorangan atau usaha kecil dan menengah pasti lebih berdampak luas dibandingkan dengan pencurian atau korupsi senilai ratusan juta rupiah di perusahaan besar.

Penelitian tentang intensitas etis yang dilakukan McMahon dan Harvey (2007); Ng et al. (2009); Sweeney dan Costello (2009); dan Musbah (2010); mengungkap "bahwa besarnya konsekuensi dan konsensus sosial (magnitude of consequences and social consensus) adalah faktor-faktor yang paling signifikan di dalam menjelaskan kesadaran etis serta pertimbangan etis individuindividu." Sweeney dan Costello (2009) dan Musbah (2010) mengungkapkan bahwa temporal immediacy mempunyai hubungan signifikan dengan pengambilan keputusan etis. Sedangkan Nguyen dan Biderman (2008) dan Musbah (2010) menemukan bahwa intensitas etis pada tiga dimensi pertama berhubungan secara positif dengan pengambilan keputusan etis.

\section{Dampak Kode Etik pada Pengaruh Filosofi Etis dan Intensitas Etis terhadap Kesadaran Etis Akuntan Publik}

Kode etik (code of ethics) berisi pernyataan-pernyataan umum, selalu mementingkan kepentingan orang lain atau bersifat mendatangkan ilham, yang memberi prinsip-prinsip dan dasar pada aturanaturan pelaksanaan (rules of conduct). Kode etik biasanya menspesifikasi cara-cara melaporkan pelanggaran, tindakan pendisiplinan untuk setiap pelanggaran, dan suatu struktur untuk proses-proses. Walaupun ada perbedaan di dalam teori antara suatu kode etik, aturan pelaksanaan, dan pernyataan nilai-nilai, namun penting diketahui bahwa kedua terminologi tersebut seringkali digunakan untuk suatu maksud yang sama (interchangeably) (Ferrell et al., 2011).

Keberadaan kode etik profesional memperlihatkan bagaimana pertimbangan etis dilakukan di dalam akuntansi, sebagaimana informasi akuntansi juga dikembangkan berdasarkan konflik etis. Penelitian tersebut memperlihatkan beberapa dilema etis yang dihadapi oleh para akuntan di dalam lingkungan di mana keputusan akuntansi dibuat dengan pendekatan teori kognitif bersyarat (cognitive-contingency theory) (Ferrell et al., 2011). 
Teori kognitif bersyarat tersebut, dapat digunakan untuk menjelaskan dan memprediksi perilaku etis oleh para akuntan, dengan cara mengganti faktor-faktor yang mempengaruhi perilaku yang telah diketahui dengan faktor-faktor individual, situasional dan organisasi dalam menghasilkan keputusan-keputusan yang paling etis.

Kode etik mempunyai dampak positif pada kualitas pertimbangan etis yang dibuat oleh akuntan profesional dan mengargumentasi bahwa kode etik di dalam konteks pengalaman yang lebih umum akan mengakibatkan kualitas pertimbangan etis yang lebih tinggi (Croxford, 2010). Hal tersebut mendasari usulan Internasional Standard on Quality Control 1 (ISQC 1) dan relevan terhadap pengendalian mutu kantor akuntan publik yang berpotensi mempengaruhi secara positif terhadap kinerja audit yang berkualitas. Kantor akuntan publik disarankan menyelenggarakan pelatihan dan mengedarkan kepada karyawan kode etik dan prinsip etika organisasi (Pflugrath et al., 2007).

Kode etik dapat digunakan pada berbagai situasi, dari mulai operasi internal presentasi bagian penjualan sampai praktik pengungkapan keuangan. Penelitian menemukan bahwa kode etik perusahaan umumnya berisi kurang lebih enam nilai atau prinsip-prinsip penting sebagai tambahan penjelasan lebih terinci dan contohcontoh pelaksanaan yang dianjurkan. Enam nilai yang diusulkan di dalam suatu kode etik termasuk: (1) bersifat dapat dipercaya, (2) rasa hormat, (3) pertanggungan jawab, (4) kejujuran, (5) kepedulian, dan (6) kewarganegaraan (citizenship).

Kode etik di dalam suatu ikatan atau asosiasi profesi menggambarkan suatu konsensus bersama yang dibuat untuk dipatuhi oleh semua anggotanya. Setiap pelanggaran yang dapat terdeteksi akan mendapatkan tindakan pendisiplinan yang ditentukan oleh komite etika atau dewan kehormatan profesinya. Kode etik harus ditetapkan secara tertulis dan mengikat semua anggota untuk mematuhinya.

McKinney et al. (2010) mengungkapkan bahwa "professional business yang bekerja di perusahaan dengan kode etik tertulis cenderung mendapatkan situasi adanya masalah yang dipertanyakan secara etis menjadi kurang dapat diterima dibandingkan dengan perusahaan-perusahaan yang tanpa kode etik tertulis". Demikian juga dengan para manajer sampai pada keputusan yang etis dengan pengalaman dan nilainilai yang mereka miliki sendiri, dan ditambah dengan adanya standar etis dan praktiknya di tempat kerja mereka, (Pflugrath et al., 2007 dan Elango et al., 2010). Hasil penelitian tersebut memperkuat hasil penelitian yang dilakukan oleh Maree dan Radloff (2007) yang menunjukkan bahwa kode etik berpengaruh terhadap pertimbangan etis akuntan.

Penelitian yang dilakukan oleh Ross dan Robertson (2003) menguji pengaruh moderasi yang terjadi di antara ke empat variabel dependen (ethical recognition, ethical judgments, ethical intention dan ethical behavior). Hasil penelitian tersebut mengungkapkan bahwa moderasi antara pertimbangan etis dengan iklim etis pada intensi etis didukung oleh tanggungjawab sosial dan aturan-aturan, kode etik serta iklim etis. Berdasarkan argumentasi penelitian tersebut, maka dapat dikembangkan hipotesis berikut ini:

$\mathrm{H}_{\text {.1a: }}$ Kode etik memperkuat pengaruh positif filosofi etis - idealisme terhadap kesadaran etis akuntan publik.

H.1b: Kode etik memperkuat pengaruh negatif filosofi etis - relativisme terhadap kesadaran etis akuntan publik.

H.1c: Kode etik memperkuat pengaruh positif intensitas etis - magnitude consequence terhadap kesadaran etis akuntan publik.

H.1d: Kode etik memperkuat pengaruh positif intensitas etis - social 
consensus terhadap kesadaran etis akuntan publik.

H.1e: Kode etik memperkuat pengaruh positif intensitas etis-temporal immediacy terhadap kesadaran etis akuntan publik.

Dampak Kode etik pada Pengaruh Filosofi Etis dan Intensitas Etis terhadap Pertimbangan Etis Akuntan Publik

Hasil penelitian Pflugrath et al. (2007) mendukung keberadaan kode etik yang diungkapkan mempunyai dampak positif pada peningkatan kualitas pertimbangan etis yang dilakukan oleh akuntan profesional. Selain itu suatu kode etik yang di terapkan di suatu KAP profesional juga terlihat mempunyai pengaruh signifikan pada pertimbangan audit oleh akuntan profesional tertentu di dalamnya dibandingkan mahasiswa akuntansi (Pflugrath et al., 2007 dan Elango et al., 2010).

Kode etik mempengaruhi pertimbangan etis pada situasi adanya intensitas etis yang tinggi. Demikian juga budaya etis secara tidak langsung berhubungan dengan pertimbangan etis pada situasi intensitas etis yang tinggi, sebagaimana pengaruh idealisme yang mempengaruhi pertimbangan etis. Orientasi dan pertimbangan etis hanya dapat berhubungan pada situasi intensitas etis yang tinggi. Selanjutnya individu di perusahaan dengan komitmen organisasi yang lebih tinggi kurang berminat untuk terlibat perilaku tidak etis yang dapat meningkatkan keuntungan organisasi yang berdampak menyusahkan masyarakat, dibandingkan individu dengan komitmen organisasi lebih rendah pada perusahaan yang sama (Cullinan et al., 2008 dan Craft, 2013).

Berdasarkan argumentasi penelitian tersebut, maka dapat dikembangkan hipotesis kode etik yang memperkuat pengaruh filosofi etis dan intensitas etis terhadap pertimbangan etis berikut ini:
H.2a: Kode etik memperkuat pengaruh positif filosofi etis - idealisme terhadap pertimbangan etis akuntan publik.

$\mathrm{H}_{.2 b}$ : Kode etik memperkuat pengaruh negatif filosofi etis - relativisme terhadap pertimbangan etis akuntan publik

$\mathrm{H}_{2 \mathrm{2c}}$ : Kode etik memperkuat pengaruh positif intensitas etis - magnitude consequence terhadap pertimbangan etis akuntan publik.

$\mathrm{H}_{\text {.2d: }}$ Kode etik memperkuat pengaruh positif intensitas etis - social consensus terhadap pertimbangan etis akuntan publik.

$\mathrm{H}_{\text {.2e: }}$ Kode etik memperkuat pengaruh positif intensitas etis - temporal immediacy terhadap pertimbangan etis akuntan publik.

Dampak Kode etik pada Pengaruh Filosofi Etis dan Intensitas Etis terhadap Intensi Etis Akuntan Publik

Terdapat suatu hubungan yang signifikan antara anggota asosiasi akuntan profesional yang sudah senior dalam perkembangan etis dengan pilihan untuk melakukan suatu tindakan etis atau tindakan tidak etis. Akuntan profesional senior yang telah mendapatkan pelatihan auditing dengan penekanan pada semangat kepatuhan pada kode etik lebih berintensi untuk melakukan suatu perilaku etis. Kode etik mempengaruhi persepsi para manajer untuk memperluas analisis dalam memperluas permasalahan etis tertentu. Demikian juga penegakan suatu kode etik tertentu berhubungan dengan perilaku etis berdasarkan data dari sub-kontraktor dan bagian riset perusahaan. Kode etik dan sanksi-sanksinya yang telah dikomunikasikan dengan baik akan memicu individuindividu untuk lebih berperilaku secara etis, dan berhubungan dengan kemampuan perilaku etis dalam penjualan (Ford dan Richardson, 1994). 
Berdasarkan argumentasi penelitian tersebut, maka dapat dikembangkan hipotesis kode etik yang memperkuat pengaruh filosofi etis dan intensitas etis terhadap intensi etis berikut ini:

H.за: Kode etik memperkuat pengaruh positif filosofi etis - idealisme terhadap intensi etis akuntan publik.

H.зb: Kode etik memperkuat pengaruh negatif filosofi etis - relativisme terhadap intensi etis akuntan publik.

H.зc: Kode etik memperkuat pengaruh positif intensitas etis - magnitude consequence terhadap intensi etis akuntan publik.

H.3d: Kode etik memperkuat pengaruh positif intensitas etis - social consensus terhadap intensi etis akuntan publik.

H.зе: Kode etik memperkuat pengaruh positif intensitas etis - temporal immediacy terhadap intensi etis akuntan publik.

\section{METODE PENELITIAN Variabel dan Pengukuran Filosofi Etis}

Filosofi etis - idealisme dan relativisme adalah variabel independen yang merupakan perspektif ideal yang memberi dasardasar yang abstrak kepada individuindividu untuk menuntun pada keberadaan sosial mereka. Pembagian filosofi etis ke dalam dua dimensi (idealisme dan relativisme) didasarkan pada taxonomy ideologi etis yang utama menurut Forsyth (1980). Referensi kuesioner menggunakan format Ethics Position Questionnaire (EPQ) dari Musbah (2010). EPQ ini bertujuan mengukur filosofi etis pribadi auditor kantor akuntan publik yang terdiri dari idealisme dan relativisme. Instrumen ini telah banyak digunakan dan divalidasi oleh banyak peneliti (Chan dan Leung, 2006; Marques dan Azevedo-Pereira, 2009; dan Shafer, 2008).

$E P Q$ terdiri atas dua skala, masingmasing terdiri atas 10 butir pertanyaan. Pertama digunakan untuk mengukur idea- lisme dan yang kedua untuk relativisme. Duapuluh butir ini dilengkapi skala jawaban yang didasarkan pada lima peringkat berdasarkan tingkat kesetujuannya (angka 1 untuk skor sangat tidak setuju sampai dengan 5 untuk skor sangat setuju).

\section{Intensitas Etis}

Instrumen intensitas etis diadopsi dari Musbah (2010) yang mengukur tiga elemen pada intensi etik yaitu: Besarnya konsekuensi (magnitude consequence) diukur dengan "besarnya kerugian (jika ada) sebagai akibat dari suatu tindakan adalah sangat kecil atau sebaliknya"; konsensus sosial (social concensus) diukur dengan "kebanyakan orang setuju bahwa tindakan itu salah"; dan kedekatan waktu sementara (temporal immediacy) diukur dengan "tindakan pembuat keputusan tidak akan segera menyebabkan kerugian apapun di masa yang akan datang". Pengukuran ini didasarkan pada Jones (1991).

\section{Kode etik}

Pengukuran variabel situasional kode etik adalah dengan menggunakan daftar pertanyaan sebanyak 25 pertanyaan tentang pemahaman responden pada penerapan kode etik (Musbah, 2010).

\section{Sampel dan Metode Pengumpulan Data Sampel}

Populasi penelitian ini adalah akuntan publik yang bekerja sebagai auditor di kantor akuntan publik. Teknik pengambilan sampel dilakukan dengan judgment sampling yaitu pengambilan sampel berdasarkan pertimbangan tertentu atas responden yang diinginkan. Selain itu responden yang dilibatkan harus memiliki pengetahuan dan pengalaman yang cukup tentang profesinya yaitu akuntansi, yang bekerja sebagai auditor di kantor akuntan publik.

Penentuan ukuran sampel dengan pertimbangan atas kualifikasi keahlian responden yang disesuaikan dengan tujuan dan masalah penelitian (purposive sampling). Elemen populasi yang dipilih sebagai 
sampel dibatasi pada elemen-elemen yang dapat memberikan informasi berdasarkan pertimbangan-pertimbangan yang relevan.

\section{Metode Pengumpulan Data}

Distribusi kuesioner dilakukan dalam dua tahap, pertama merupakan riset lapangan pendahuluan yang bertujuan melakukan uji coba kuesioner apakah dapat dengan efektif menangkap data variabel yang diperlukan untuk pengolahan, dan apakah kuesioner yang disebarkan tidak menjadikan responden merasa terbebani dan akhirnya enggan untuk menjawab kuesioner tersebut. Kedua adalah penyebaran kuesioner akhir untuk mendapatkan data.

Penyebaran kuesioner penelitian diusahakan dengan beberapa ketentuan untuk menghindari jawaban responden yang bersifat normatif. Adapun ketentuan tersebut adalah (1) penyebaran kuesioner di kantor akuntan publik dilakukan secara simultan dan berurutan waktu sesuai dengan kecukupan waktu responden, (2) penyebaran kuesioner di tempat seminar dan lokakarya dilakukan dengan pendistribusian di tempat dan kemudian peng ambilan di kantor Akuntan Publik yang bersedia mengisi kuesioner.

\section{Metoda Analisis Data}

Uji hipotesis dilaksanakan dengan Moderated Regresion Analysis (MRA) yang merupakan aplikasi khusus regresi berganda linear dengan persamaan regresinya mengandung unsur (perkalian dua atau lebih variabel bebas).

\section{ANALISIS DAN PEMBAHASAN \\ Hasil Uji Regresi \\ Variabel Idealisme}

Hasil pengujian menunjukkan bahwa terdapat pengaruh positif filosofi etisidealisme terhadap kesadaran etis akuntan publik, hal ini ditunjukkan dengan nilai $p$ value sebesar 0,040 dengan arah positif. Namun dengan pengujian variabel pemode- rasi kode etik (hasil uji hipotesis $\mathrm{H}_{\text {.1a) }}$ menunjukkan bahwa kode etik tidak mampu memperkuat pengaruh positif filosofi etis-idealisme terhadap kesadaran etis akuntan publik. Pengaruh kode etik ini memiliki pengaruh negatif yang berarti bersifat memperlemah pengaruh idealisme dengan nilai pengaruh sebelum faktor situasional kode etik menjadi negatif (0,318). Individu-individu akuntan publik dengan filosofi etis dimensi idealisme yang tinggi mempunyai kecenderungan tidak memperhatikan kode etik, atau implementasi kode etik akan banyak menurunkan individu-individu akuntan publik dengan idealisme tinggi di dalam meningkatkan kesadaran etis karena turunnya kesempatan untuk memikirkan kesadaran etis berdasarkan filosofi pemikiran.

Hasil pengujian variabel filosofi etisidealisme terhadap pertimbangan etis menunjukkan pengaruh yang tidak signifikan filosofi etis-idealisme terhadap pertimbangan etis ( $p$-value 0,365). Demikian juga hasil uji hipotesis H.2a menunjukkan bahwa kode etik memperkuat pengaruh positif filosofi etis-idealisme terhadap pertimbangan etis akuntan publik tidak mendapat dukungan empirik. Uji tersebut dapat dilihat pada nilai signifikansi $p$-value sebesar $0,259>0,05$. Pernyataan ini mengungkap bahwa kode etik tidak memperkuat pengaruh positif filosofi etis dimensi idealisme terhadap pertimbangan etis akuntan publik.

Hasil pengujian variabel filosofi etisidealisme terhadap intensi etis menunjukkan pengaruh yang tidak signifikan filosofi etis-idealisme terhadap intensi etis ( $p$-value sebesar 0,095). Hasil yang sama pada pengujian hipotesis $\mathrm{H}_{\text {.za }}$ menunjukkan bahwa kode etik memperkuat pengaruh positif filosofi etis-idealisme terhadap intensi etis akuntan publik tidak mendapat dukungan empirik. Uji tersebut dapat dilihat pada nilai signifikansi $P$-value sebesar 0,359>0,05. Pernyataan ini mengungkap bahwa kode etik tidak mempunyai pengaruh yang 
memperkuat pengaruh positif filosofi etis dimensi idealisme terhadap intensi etis akuntan publik.

\section{Variabel Relativisme}

Hasil pengujian variabel filosofi etisrelativisme terhadap kesadaran etis akuntan publik menunjukkan bahwa terdapat pengaruh positif filosofi etis-relativisme terhadap kesadaran etis akuntan publik, hal ini ditunjukkan dengan nilai p-value sebesar 0,007 dengan arah positif. Namun demikian pengujian variabel pemoderasi kode etik (hasil uji hipotesis $H_{\text {.1b }}$ ) menunjukkan bahwa kode etik tidak mampu memperkuat pengaruh positif filosofi etis-relativisme terhadap kesadaran etis akuntan publik ( $p$ value sebesar 0,389>0,05). Pernyataan ini mengungkap kode etik tidak mampu memperkuat pengaruh filosofi etis dimensi relativisme terhadap kesadaran etis akuntan publik.

Hasil pengujian variabel filosofi etisrelativisme terhadap dimensi kedua dari pengambilan keputusan etis yaitu pertimbangan etis akuntan publik menunjukkan bahwa terdapat pengaruh positif filosofi etis-relativisme terhadap pertimbangan etis akuntan publik, hal ini ditunjukkan dengan nilai p-value sebesar 0,001 dengan arah positif. Namun dengan pengujian variabel pemoderasi kode etik (hasil uji hipotesis $\mathrm{H}_{.2 \mathrm{~b}}$ ) menunjukkan bahwa kode etik tidak mampu memperkuat pengaruh positif filosofi etis-relativisme terhadap pertimbangan etis akuntan publik ( $p$ value sebesar 0,130>0,05). Pernyataan ini mengungkap kode etik tidak mampu memperkuat pengaruh filosofi etis dimensi relativisme terhadap pertimbangan etis akuntan publik.

Hasil pengujian variabel filosofi etisrelativisme terhadap dimensi ketiga dari pengambilan keputusan etis yaitu intensi etis akuntan publik menunjukkan bahwa terdapat pengaruh positif filosofi etisrelativisme terhadap intensi etis akuntan publik, hal ini ditunjukkan dengan nilai $p$ value sebesar 0,000 dengan arah positif.
Namun dengan pengujian variabel pemoderasi kode etik (hasil uji hipotesis $\mathrm{H}_{.3 \mathrm{~b}}$ ) menunjukkan bahwa kode etik tidak mampu memperkuat pengaruh positif filosofi etis-relativisme terhadap intensi etis akuntan publik (p-value sebesar 0,226>0,05). Pernyataan ini mengungkap kode etik tidak mampu memperkuat pengaruh filosofi etis dimensi relativisme terhadap intensi etis akuntan publik.

\section{Variabel magnitude consequence}

Hasil pengujian variabel magnitude consequence terhadap dimensi-dimensi pengambilan keputusan etis yaitu kesadaran etis, pertimbangan etis, dan intensi etis menunjukkan bahwa variabel magnitude consequence tidak berpengaruh terhadap satupun dimensi pengambilan keputusan etis. Hasil pengujian hipotesis yang memasukkan variabel kode etik sebagai variabel moderasi tidak mendapat dukungan secara empirik (hipotesis H.1c memiliki $p$ value sebesar $0,825>0,05, H$. 2c memiliki $p$ value sebesar $0,173>0,05$; H.3c memiliki $p$ value sebesar $0,996>0,05)$. Dengan demikian kode etik tidak memperkuat pengaruh intensitas etis dimensi magnitude consequence terhadap kesadaran etis, pertimbangan etis, dan intensi etis akuntan publik.

\section{Variabel Social Consensus}

Hasil pengujian variabel social consensus terhadap kesadaran etis akuntan publik menunjukkan koefisien beta sebesar 0.571 dengan arah positif dan p-value 0.000 . Dengan demikian hasil pengujian menunjukkan adanya pengaruh positif variabel social consensus terhadap kesadaran etis akuntan publik. Demikian juga dengan hasil pengujian social consensus terhadap pertimbangan etis akuntan publik menunjukkan koefisien beta sebesar 0,647 dengan arah positif dan p-value 0,000. Dengan demikian hasil pengujian menunjukkan adanya pengaruh positif variabel social consensus terhadap pertimbangan etis akuntan publik. Namun hasil pengujian variabel social consensus terhadap intensi etis akuntan 
publik menunjukkan koefisien beta sebesar -0,017 dengan arah negatif dan p-value 0797 . Dengan demikian hasil pengujian menunjukkan bahwa variabel social consensus tidak berpengaruh terhadap intensi etis akuntan publik.

Hasil pengujian hipotesis yang memasukkan variabel kode etik sebagai variabel moderasi pada uji hipotesis $\mathrm{H}_{\text {.1d }}$ menunjukkan bahwa kode etik memperkuat pengaruh positif intensitas etis-social consensus terhadap kesadaran etis akuntan publik tidak mendapat dukungan secara empirik. Uji tersebut dapat dilihat pada beta coefficient yang bersifat negatif sebesar ($0,054)$ dengan nilai signifikansi p-value sebesar 0,003>0,05 (signifikansi 5\%). Hasil pengujian ini mengungkap bahwa kode etik memperlemah pengaruh positif intensitas etis dimensi social consensus terhadap kesadaran etis akuntan publik.

Hasil uji hipotesis $\mathrm{H}_{\text {.2d }}$ menunjukkan bahwa kode etik memperkuat pengaruh positif intensitas etis-social consensus terhadap pertimbangan etis akuntan publik tidak mendapat dukungan secara empirik. Uji tersebut dapat dilihat pada nilai signifikansi $p$-value sebesar 0,069<0,05 (signifikansi 5\%). Kode etik tersebut tidak memperkuat pengaruh positif social consensus pada pertimbangan etis akuntan publik. Namun jika diuji dengan tingkat signifikansi $10 \%$, maka kode etik dapat memperlemah pengaruh positif social consensus terhadap pertimbangan etis, yang sebelum nya bersifat positif $(0,647)$ menjadi negatif ($0,352)$. Kekuatan bersifat negatif tersebut adalah $-0,999$. Kekuatan yang memperlemah ini menggambarkan bahwa kode etik dan social consensus adalah faktor-faktor yang mengambil bagian atau saling mengisi dalam mempengaruhi pertimbangan etis akuntan publik. Hasil uji hipotesis H.3d menunjukkan bahwa kode etik memperkuat pengaruh positif intensitas etis-social consensus terhadap intensi etis akuntan publik tidak mendapat dukungan secara empirik.
Uji tersebut dapat dilihat pada nilai signifikansi $p$-value sebesar 0,865 >0,05 (signifikansi 5\%). Pernyataan ini mengungkapkan bahwa kode etik tidak memperkuat pengaruh positif intensitas etis dimensi social consensus terhadap intensi etis akuntan publik.

\section{Variabel Temporal Immediacy}

Hasil pengujian variabel temporal immediacy terhadap dimensi-dimensi pengambilan keputusan etis yaitu kesadaran etis, pertimbangan etis, dan intensi etis menunjukkan bahwa variabel temporal immediacy tidak berpengaruh terhadap dimensi kesadaran etis dan pertimbangan etis akuntan publik, namun berpengaruh terhadap dimensi intensi etis. Hasil pengujian hipotesis yang memasukkan variabel kode etik sebagai variabel moderasi tidak mendapat dukungan secara empirik (hipotesis H.1e : p-value sebesar $0,376>0,05, \mathrm{H}$. 2e: $p$-value sebesar 0,181 >0,05; H.3e: $p$-value sebesar $0,254>0,05>0,05)$. Dengan demikian kode etik tidak memperkuat pengaruh intensitas etis dimensi temporal immediacy terhadap kesadaran etis, pertimbangan etis, dan intensi etis akuntan publik. Ringkasan hasil uji hipotesis dapat dilihat pada Tabel 1.

\section{Pembahasan}

Hasil pengujian hipotesis menunjukkan bahwa kode etik ini bersifat memperlemah pengaruh idealisme. Hasil ini tidak sesuai dengan dugaan awal bahwa kode etik memperkuat pengaruh idealisme terhadap pengambilan keputusan etis. Hal ini menunjukkan bahwa individu akuntan publik dengan filosofi etis dimensi idealisme yang tinggi mempunyai kecenderungan tidak memperhatikan kode etik, atau implementasi kode etik akan banyak menurunkan individu-individu akuntan publik dengan idealisme tinggi di dalam meningkatkan kesadaran etis karena turunnya kesempatan untuk memikirkan kesadaran etis berdasarkan filosofi pemikiran. Hasil penelitian 
bahwa faktor situasional kode etik mempunyai pengaruh negatif pada pengaruh positif filosofi etis-idealisme terhadap kesadaran etis, bermakna bahwa kode etik mendorong akuntan publik untuk meng- ikuti aturan-aturan etik yang universal dalam mencapai hasil yang terbaik, seperti yang digambarkan Forsyth (1980) dalam taxonomy of ethical ideology.

Tabel 1

Hasil Uji Regresi

\begin{tabular}{|c|c|c|c|c|c|c|}
\hline \multirow[t]{2}{*}{$\begin{array}{l}\text { Variabel independen } \\
\text { dan moderasi }\end{array}$} & \multicolumn{2}{|c|}{$\underset{\substack{\text { Kara } \\
(K E)}}{\text { Kesad }}$ Etis } & \multicolumn{2}{|c|}{$\begin{array}{c}\text { Pertiml } \\
\substack{3 a n \\
(P E)}\end{array}$} & \multicolumn{2}{|c|}{$\begin{array}{c}\text { Intel } \\
\substack{\text { (ai } \\
(I E)}\end{array}$} \\
\hline & Koef. & p-Value & Koef. & p-Value & Koef. & p-Value \\
\hline Konstanta & .019 & & .696 & & 2.870 & \\
\hline Idealisme & .116 & .040 & .046 & .365 & -.093 & .095 \\
\hline Relativisme & .094 & .007 & 101 & .001 & .172 & .000 \\
\hline Magnitude Consequence & .057 & .372 & -.002 & .972 & .107 & .088 \\
\hline Social Concensus & .571 & .000 & .647 & .000 & -.017 & .797 \\
\hline Temporal Immediacy & -.083 & 269 & -.029 & .663 & 436 & .000 \\
\hline $\mathrm{I}^{*}$ Kode etik & -.318 & .033 & .151 & 259 & 139 & 359 \\
\hline $\mathrm{R}^{*}$ Kode etik & .066 & .389 & -.105 & 130 & -.095 & 226 \\
\hline$M C^{*}$ Kode etik & .037 & .825 & -.205 & 173 & .001 & 996 \\
\hline$S C^{\star}$ Kode etik & -.054 & .801 & -.352 & .069 & -.037 & .865 \\
\hline$T I^{*}$ Kode etik & -.198 & .376 & .270 & .181 & 261 & .254 \\
\hline
\end{tabular}

Taxonomy, salah satunya menjelaskan posisi situationists yang merupakan perpaduan idealisme yang tinggi/kuat yang mengusulkan implementasi aturan etik universal dengan relativisme tinggi, sehingga dalam hal ini pertimbangan atas pemikiran idealis menjadi kurang diperlukan karena sudah ada kode etik, dan faktor tersebut menjadi saling mengisi atau mengambil bagian bersama dengan idealisme di dalam mempengaruhi kesadaran etis akuntan publik.

Situationists yang berarti mengikuti aturan-aturan etik universal untuk mencapai hasil terbaik merupakan idealisme tinggi karena menggambarkan sudah ada pemikiran baik sebelum ada pemikiran yang fokus pada suatu isu etis sebagai fakta empirik. Selanjutnya pertimbangan berada pada posisi relativisme tinggi karena sesuai fakta empirik juga relativisme mempengaruhi signifikan terhadap kesadaran etis akuntan publik.

Hasil pengujian variabel lainnya menunjukkan bahwa kode etik memperkuat pengaruh negatif filosofi etis-relativisme terhadap pengambilan keputusan etis yang terdiri atas kesadaran etis, pertimbangan etis, dan intensi etis akuntan publik tidak mendapat dukungan secara empirik. Hasil penelitian ini menunjukkan bahwa kode etik sebagai prinsip-prinsip etik tidak digunakan oleh akuntan publik melainkan lebih menggunakan nilai-nilai personal dalam penilaian. Perpaduan ini juga telah digambarkan oleh taxonomy of ethical ideology, sebagai perpaduan yang disebut subjectivists (relativisme-subyektifistik).

Demikian juga dengan hasil pengujian kode etik terhadap variabel intensitas etis menunjukkan bahwa kode etik memperkuat pengaruh positif intensitas etis-magnitude consequence terhadap kesadaran etis akuntan publik tidak mendapat dukungan secara empirik. Faktor situasional kode etik tidak mempunyai pengaruh memperkuat pengaruh positif intensitas etis-magnitude consequence terhadap kesadaran etis akuntan publik, mengandung makna bahwa besarnya untung atau rugi sudah merupakan pemikiran yang kuat pada individu-individu akuntan publik berdasarkan sampel. 
Kode etik sebagai prinsip-prinsip etis universal yang tertulis menjadi fokus perhatian hanya pada saat isu etis terjadi atau dihadapi oleh salah seorang dari akuntan publik.

Berdasarkan fakta bahwa kode etik sebagai prinsip-prinsip etis universal yang tertulis merupakan representasi dari idealisme, menunjukkan relativisme tinggi karena kode etik tidak memperkuat pengaruh magnitude consequence terhadap kesadaran etis akuntan publik. Magnitude consequence yang merepresentasi relativisme tidak berpengaruh pada kesadaran etis sebelum adanya kode etik menggambarkan relativisme rendah, sehingga menjadi idealisme tinggi. Idealisme dan relativisme tinggi merupakan representasi perpaduan situationists di dalam taxonomy of ethical ideology.

Hasil pengujian kode etik yang diharapkan memperkuat pengaruh positif intensitas etis-social consensus terhadap kesadaran etis akuntan publik tidak mendapat dukungan secara empirik. Hal ini mengisyaratkan makna bahwa terdapat kesamaan yang mendasar antara kode etik dengan social consensus. Kode etik adalah sarana untuk memasukkan konsensus-konsensus yang telah disepakati bersama oleh IAPI menjadi dasar kesadaran etis akuntan publik.

Hasil pengujian kode etik terhadap dimensi temporal immediacy menunjukkan bahwa kode etik tidak memperkuat pengaruh positif intensitas etis dimensi temporal immediacy terhadap kesadaran etis akuntan publik. Kode etik yang merupakan representasi dari idealisme bermakna lemah karena tidak berpengaruh memperkuat pengaruh temporal immediacy terhadap kesadaran etis akuntan publik mengindikasikan relativisme tinggi. temporal immediacy tidak berpengaruh terhadap kesadaran etis akuntan publik sebelum adanya kode etik bermakna lemah pengaruhnya terhadap kesadaran etis, mengindikasikan idealisme tinggi.
Perpaduan social consensus kuat atau tinggi yang merepresentasi relativisme tinggi dan kode etik yang tidak mempunyai pengaruh memperkuat pengaruh positif social consensus terhadap kesadaran etis yang merepresentasi idealisme rendah, menggambarkan posisi taxonomy of ethical ideology subjectivistis (Forsyth, 1980), sedangkan perpaduan idealisme tinggi dan temporal immediacy lemah yang merupakan indikasi relativisme rendah menggambarkan posisi absolutists.

Hasil pengujian atas peran variabel kode etik terhadap pengaruh idealisme, relativisme, dan tiga dimensi intensitas etis terhadap pertimbangan etis menunjukkan bahwa kode etik tidak mampu memperkuat pengaruh positif idealisme terhadap pertimbangan etis akuntan publik. Hal ini mengambarkan bahwa prinsip-prinsip etik digunakan di dalam menuntun kebijakan, tetapi terbuka untuk pengecualian secara pragmatis. Di dalam taxonomy of ethical ideology digambarkan sebagai perpaduan situationists. Idealisme yang tidak berpengaruh pada pertimbangan etis mengindikasikan idealisme lemah atau relativisme tinggi dan idealisme tinggi juga karena kode etik tidak memperkuat pengaruh idealisme pada pertimbangan etis sebagai faktor individual, sehingga menjadikan idealisme tinggi dan relativisme tinggi.

Hasil pengujian kode etik terhadap dimensi ketiga dari pengambilan keputusan etis yaitu intensi etis yang diharapkan dapat memperkuat pengaruh positif filosofi etisidealisme terhadap intensi etis akuntan publik tidak mendapat dukungan empirik. Hal ini mengisyaratkan bahwa pada tahap intensi etis jika dipandang dari taxonomy of ethical ideology, maka akuntan publik berada pada perpaduan situationists atau idealisme tinggi yang direpresentasi oleh kode etik yang tidak memperkuat pengaruh idealisme terhadap pertimbangan etis dan relativisme tinggi sebelum ada pengaruh kode etik sebagai faktor situasional. 
Demikian juga dengan filosofi etisrelativisme terhadap intensitas akuntan publiktidak mendapat dukungan empirik. Hal ini bermakna bahwa akuntan publik berada pada perpaduan subyectivists di dalam taxonomy of ethical ideology (Forsyth 1980). Perpaduan subjectivists terjadi pada saat relativisme tinggi yang berpengaruh kuat terhadap intensi etis sebelum pengaruh faktor situasional, dan kode etik lemah sebagai representasi idealisme yang rendah.

Hasil pengujian kode etik yang diharapkan mampu memperkuat pengaruh positif intensitas etis-magnitude consequence terhadap intensi etis akuntan publik tidak mendapat dukungan empirik. Hal ini menunjukkan bahwa akuntan publik berdasarkan sampel berada pada perpaduan situationist dalam taxonomy of ethical ideology (Forsyth, 1980). Situationists merupakan perpaduan filosofi etis relativisme tinggi yang direpresentasikan oleh kode etik yang tidak memperkuat atau lemah, dan magnitude consequence yang tidak berpengaruh pada intensi etis sebelum pengaruh faktor situasional kode etik artinya relativisme rendah atau idealisme tinggi.

Demikian juga hasil pengujian pada dimensi intensitas etis-social consensus terhadap intensi etis akuntan public tidak mendapat dukungan secara empirik. Hal ini menunjukkan bahwa akuntan publik berada pada perpaduan situationists dalam taxonomy of ethical ideology. Perpaduan tersebut menggambarkan pengaruh yang lemah dari kode etik sebagai representasi dari relativisme tinggi dan social consensus sebagai representasi dari relativisme rendah karena tidak berpengaruh pada kode etik, sehingga merupakan idealisme tinggi.

Pada dimensi temporal immediacy terhadap intensi etis akuntan publik, kode etik juga tidak mampu memperkuat pengaruh positif intensitas etis dimensi temporal immediacy terhadap intensi etis akuntan publik, bermakna bahwa akuntan publik berdasarkan hasil sampel masuk dalam perpaduan subjectivists. Perpaduan subjec- tivists terjadi karena idealisme rendah yang direpresentasikan oleh kode etik lemah tidak berpengaruh pada intensi etis, dan temporal immediacy kuat yang merepresentasikan relativisme tinggi.

\section{SIMPULAN, KETERBATASAN DAN IMPLIKASI \\ Simpulan}

Berdasarkan analisis yang telah dilakukan, maka simpulan hasil penelitian ini adalah terdapat dampak yang memperkuat faktor-faktor situasional pada pengaruh faktor-faktor individual dalam pengambilan keputusan etis yaitu: (1) Terdapat dampak kode etik pada pengaruh idealisme terhadap kesadaran etis, sementara pada relativisme, magnitude consequence, social consensus, dan temporal immediacy tidak berpengaruh pada pengambilan keputusan etis akuntan publik, (2) Kode etik tidak mempunyai pengaruh pada semua pengaruh dimensi-dimensi pada faktor-faktor individual filosofi etis dan intensitas etis terhadap pertimbangan etis akuntan publik, (3) Kode etik tidak mempunyai pengaruh yang memperkuat pengaruh idealisme, relativisme, magnitude consequence, social consensus dan temporal immediacy terhadap intensi etis akuntan publik.

\section{Keterbatasan}

Keterbatasan penelitian ini adalah: (1) Penyebaran kuesioner penelitian belum mempertimbangkan situasional kritis dan non kritis respondennya. Waktu yang berbeda-beda responden dapat berada pada kondisi pemikiran yang kritis atau tidak, maka situasi ini akan berpengaruh pada jawaban kuesioner yang diberikan, (2) Penelitian belum melibatkan narasumber dan responden yang lebih majemuk, sehingga dapat diperbandingkan lebih banyak profesi akuntan yang bekerja menurut bidang profesi yang berbeda-beda dan responden yang membedakan akuntan publik (big four dan non big four) dan akuntan publik berafiliasi lokal, (3) Jumlah responden yang mengembalikan kuesioner (me- 
ngisi) sebanyak 138 responden atau sebesar $33 \%$. Responden yang tidak mengembalikan sebanyak $(67 \%)$ belum tentu mempunyai jawaban yang sama dengan jawaban responden yang kembali. Terbatasnya jumlah kuesioner kembali (respon rate) tersebut sangat memungkinkan terjadinya bias, (4) Penelitian etis dilakukan dengan model hubungan linear padahal etis menyangkut permasalahan yang kompleks. Pengisian kuesioner penelitian dilakukan di tempat seminar, maka kemungkinan responden menjawab secara normatif, (5) Penelitian belum memperkuat fokus pada manajemen organisasi yang dapat menciptakan iklim etis dan situasional dari iklim etis, dan (6) Faktor-faktor individual yang utama dan kode etik belum dilakukan monitoring dan evaluation terus menerus. Monitoring dan evaluation terus menerus diperlukan karena telah berkembang dimensi-dimensi dari filosofi etis dan intensitas etis.

\section{Implikasi}

\section{Implikasi bagi Pengembangan Ilmu Pengetahuan}

Kode etik dan idealisme yang sifatnya positif terhadap pengambilan keputusan dan kode etik berpengaruh menurunkan peran idealisme terhadap kesadaran etis. Pengaruh yang positif dari kedua faktor tersebut menggambarkan bahwa kode etik dapat dijadikan sarana untuk penerapan pokok-pokok pikiran idealisme dalam praktik pengambilan keputusan etis. Pemikiran idealisme yang sulit diterapkan dapat disimulasikan melalui penerapan kode etik organisasi sampai tercipta iklim etis.

Temuan ini memperkuat argumentasi bahwa kode etik harus terus dikembangkan dan disosialisasi lebih mendalam. Secara teoretis sudah ada dasar pemikiran yang kuat untuk menerapkan kode etik yang penting. Adanya kode etik yang lengkap dapat menanggulangi pengaruh temporal immediacy yang terlalu kuat. Implikasi bagi lembaga pemerintah atau lembaga penyusun regulasi.

Filosofi etis dimensi idealisme berdasarkan hasil uji hipotesis terungkap mempunyai pengaruh kuat pada kesadaran etis akuntan publik. Berdasarkan temuan ini patut diungkapkan bahwa penelitian ini menyarankan untuk mempertahankan tingkat idealisme yang tinggi terus menerus, dilaksanakan kurikulum etika bisnis yang lebih komprehensif di dalam pendidikan akuntansi secara formal atau yang lebih penting lagi di dalam program pelatihan yang rutin. Di lembaga pemerintah atau penyusun regulasi, sebaiknya dipertimbangkan penempatan kaum idealis yang berfokus pada peran control saja di dalam implementasi etik.

\section{Implikasi bagi IAI dan IAPI}

Pada tahap awal, kode etik perlu diimplementasikan dengan seksama, disosialisasi dan didiskusikan dalam seminarseminar dan pelatihan yang dilakukan oleh Ikatan Akuntan Indonesia (IAI) atau Institut Akuntan Publik Indonesia (IAPI). Perhatian yang seksama terhadap kode etik dan aturan-aturan, berpengaruh besar terhadap perkembangan pertimbangan etis individu-individu dengan kesadaran etis yang tinggi. Implementasi kode etik yang terus membaik merupakan indikator bahwa iklim etis sudah mulai tumbuh, maka selanjutnya kode etik hanya diimplementasi secara khusus dalam mengatur hubungan tertentu yang belum tumbuh iklim etis.

Seminar dan lokakarya yang bertema etis secara terjadwal sangat baik untuk dikembangkan di organisasi Ikatan Akuntan Indonesia atau Institut Akuntan Publik Indonesia. Adanya seminar dan lokakarya yang terjadwal akan mempererat komunikasi antara akuntan publik terutama di dalam memecahkan permasalahan etis yang terjadi dalam praktik, menggalang terbentuknya social consensus dan mempertinggi filosofi etis para akuntan publik. 


\section{Implikasi bagi praktisi dan manajemen suatu organisasi}

Pelatihan dan seminar yang terjadwal dengan baik merupakan wadah yang baik untuk memutuskan suatu social consensus dalam mendukung keputusan etis yang sudah diputuskan bersama. Filosofi etis dimensi relativisme berdasarkan hasil uji hipotesis yang telah dilakukan, mengungkapkan bahwa ternyata beberapa akuntan publik yang menjadi responden pada penelitian ini mempunyai persepsi yang kuat dalam kesadaran etis, pertimbangan etis, dan intensi etis.

Intensitas etis dimensi magnitude consequence, social consensus dan temporal immediacy mempunyai pengaruh yang kuat terhadap kesadaran etis, pertimbangan etis dan intensi etis. Akuntan publik perlu mempertimbangkan secara seksama besarnya dampak yang ditimbulkan apakah sebagai suatu kerugian atau keuntungan dari suatu keputusan etis yang telah diambilnya. Untuk menjaga baik atau buruknya tindakan di dalam praktik diperlukan suatu konsensus masyarakat sebagai pendukung atau penyeimbang. Kemudian seorang akuntan perlu memperhatikan kedekatan waktu antara suatu tindakan etis dengan dampak yang ditimbulkannya, agar dapat melakukan penanggulangan jika terjadi suatu kecenderungan dampak dari suatu tindakan etis telah terjadi.

Pengaruh filosofi etis dimensi relativisme dan intensitas etis dimensi magnitude consequence terhadap intensi etis yang bisa berdampak kurang baik karena individuindividu cenderung akan selalu berintensi untuk melakukan suatu tindakan yang etis karena pertimbangan untung rugi saja dan dapat menggunakan segala cara untuk mempertahankan kehendaknya.

\section{DAFTAR PUSTAKA}

Ajzen, I. 1991. The Theory of Planned Behavior; Organizational Behavior and Decision Processes. Academic Press. Inc-University of Massachusetts at Amherst, MA.
Barlaup, K., H. I. Dronen, dan I. Stuart. 2009. Restoring Trust in Auditing: Ethical Discernment and The Adelphia Scandal. Managerial Auditing Journal 24(2): 183-203.

Buchan, H. F. 2005. Ethical Decision Making in the Public Accounting Profession: An Extention of Ajzen's Theory of Planned Behaviour. Journal of Business Ethics 61(2): 165-181.

Callanan G. A., P. F. Roterberry, D. F. Perri, dan P. Oehlers. 2010. Contextual Factors as Moderators of the Effect of Employee Ethical Ideology on Ethical Decission-Making. International Journal of Management 27(1): 52.

Chan, S. Y. S. dan P. Leung. 2006. The Effects if Accounting Students' Ethical Reasoning and Personal Factors on Their Ethical Sensitivity. Managerial Auditing Journal 21(4): 436-457.

Craft, L. 2013. A Review of The Empirical Ethical Decision-Making Literature 2004 - 2011; Organizational Leadership, Policy and Development. Journal of Business Ethics 117(2): 221-259.

Croxford, J. L. 2010. Determinant of Ethical Decision Making: A Study of Accountant in a Multinational Firm. Dissertation. Capella University. Minneapolis.

Cullinan, C., D. Bline, R. Farrar, dan D. Lowe. 2008. Organization Harm vs. Organization-Gain Ethical Issues: An Exploratory Examination of The Effects of Organizational Commitment. Journal of Business Ethics 80(2): 225-235.

Dickerson, C. 2009. Ethical Decision Making in Public Accounting: Investigating Factors that Influence Auditors' Ethical Sensitivity. Dissertation. Clarement Graduate University. California.

Elango B., K. Paul, S. K. Kundu, dan S. K. Paudel. 2010. Organizational Ethics, Individual Ethics, and Ethical Intentions in International Decision-Making. Journal of Business Ethics 97(4): 543-561.

Ferrell, O. C., J. Fraedrich, dan L. Ferrell. 2011. Business Ethics Ethical Decision Making and Cases. Edisi 8. South-Wes- 
tern Cengage Learning 5191 Natorp Boulevard, Mason, $\mathrm{OH} 45040$. USA.

Ford, R. C. dan W. D. Richardson. 1994. Ethical Decision Making: A Review of the Empirical Literature. Journal of Business Ethics 13: 205-221.

Forsyth, D. R. 1980. A. Taxonomy of Ethical Ideologies. Journal of Personality and Social Psycology 39(1): 175.

Gaffikin M. dan ASL. Lindawati. 2012. The Moral Reasoning of Public Accountants in The Development of a Code of Ethics: The Case of Indonesia. Australian Accounting Business and Finance Journal 6(1): 10.

Gilbert, D. R., J. A. F. Stoner, dan E. Freeman. 2009. Management. $6^{\text {th }}$ Edition. Pearson Publication.

Greenfield, Jr. A. C., C. S. Norman, dan B. Wier. 2007. The Effect of Ethical Orientation and Professional Commitment on Earnings Management Behavior. Journal of Business Ethics 83(3): 419434.

Haines, R. dan L. N. K. Leonard. 2007. Situational Influence on Ethical Decision-Making in an IT Context. Information dan Management 44(3): 313-320.

Hofmann, E., E. Hoelzl, dan E. Kirchler. 2007. A Comparison of Models Describing the Impact of Moral Decision Making on Investment Decisions. Journal of Business Ethics 82(1): 171-187.

Ionescu, L. 2010. Exploring The Ethics of Accounting. Contemporary Reading in Law and Social Justice 2(1): 158-163.

Jin, D. 2012. A Review of the Empirical Literature on Ethical Decision Making: 2004-2010. Tsinghua University-School of Economics \& Management. Center for Leadership Research and Development, SSRN.

Jones, M. T. 1991. Ethical Decision Making by Individual in Organization: An Issue-Contingent Model. The Academy of Management Review 16(2): 366-395.
Kareacer, S., R. Gohar, M. Aygun, dan C. Sayin. 2009. Effects of Personal Values on Auditor's Ethical Decisions: A Comparison of Pakistani and Turkish Professional Auditors. Journal of Busi ness Ethics 88(1): 53-64.

Leung, P. dan B. J. Cooper. 2005. Accounting, Ethical Issues and The Corporate Governance Context. Australian Accounting Review 15(35): 79-88.

Lin, C. dan Y. Ho. 2008. An Examination of Cultural Differences in Ethical Decision Making Using The Multidimensional Ethics Scale. Social Behaviour and Personality 36(9): 1213-1222.

Lv, W. L. dan Y. Huang. 2012. How Workplace Accounting Experience and Gender Affect Ethical Judgement. Social Behaviour and Personality 40(9): 14771484.

Maree, K.W. dan S. Radloff. 2007. Factor Affecting Ethical Judgement of South African Chartered Accountant. Meditari Accounting Research 15(1): 1-18.

Marques, P. A. dan J. Azevedo-Pereira. 2009. Ethical Ideology and Ethical Judgements in The Portuguese Accounting Profession. Journal of Business Ethics 86(2): 227-242.

McKinney, J. A., T. L. Emerson, dan M. J. Neubert. 2010. The Effects of Ethical Codes on Ethical Perceptions of Actions Toward Stakeholders. Journal of Business Ethics 97(4): 505-516.

McMahon, J. M. dan R. J. Harvey. 2007. The Effect of Moral Intensity on Ethical Judgment. Journal of Business Ethics 72(4): 335-357.

Musbah, A. Y. S. 2010. The Role of Individual Variables, Organizational Variables, and Moral Intensity Dimensions in Accountants' Ethical Decision Making: A Study of Management Accounting in Libya. Disertation. University of Huddersfield Business School. Queensgate, England. 
Ng, J. W., G. P. A. Lee, dan A. Moneta. 2009. Design and Validation of a Novel New Instrument for Measuring the Effect of Moral Intensity on Accountants' Provensity to Manage Earnings. Journal of Business Ethics 84(3): 367-387.

Nguyen N. T. dan M. D. Biderman. 2008. Studying Ethical Judgments and Behavioral Intentions Using Structural Equations: Evidence from the Multidimensional Ethics Scale. Journal of Business Ethics 83(4): 627-640.

Pflugrath, G., N. M. Bennie, dan C. Liang. 2007. The Impact of Codes of Ethics and Experience on Auditor Judgments. Managerial Auditing Journal 22(6): 566599.

Ross dan Robertson. 2003. A Typology of Situational Factors: Impact on Salesperson Decision-Making About Ethical
Issues. Journal of Business Ethics 46(3): 213-234.

Shafer, E. W. 2008. Ethical Climate in Chinese CPA Firms. Accounting, Organizations and Society 33(7): 825-835.

Shaw, J. 2006. Intention in Ethics. Canadian Journal of Philosophy 36(2): 187-223.

Suartana, I. W. 2010. Akuntansi KeperilakuanTeori dan Implementasi. Penerbit Andi. Yogyakarta.

Sweeney, B. dan F. Costello. 2009. Moral Intensity and Ethical Decision-Making: An Empirical Examination of Undergraduate Accounting And Business Students. Accounting Education: An International Journal 18(1): 75-97.

Wolk, H. I., J. L. Dodd., dan J. J. Rozycki. 2008. Accounting Theory: Conceptual Issues in A Political and Economic Environment. Seventh Edition. Sage Publications Inc. 